\title{
Atmospheric emissions of European SECA shipping: long-term projections
}

\author{
Juha Kalli • Jukka-Pekka Jalkanen • \\ Lasse Johansson • Sari Repka
}

Received: 4 January 2013 / Accepted: 7 August 2013 / Published online: 4 September 2013

(C) The Author(s) 2013. This article is published with open access at Springerlink.com

\begin{abstract}
We modeled the projections of the major atmospheric emissions from shipping of the European sulphur emission control area that includes the Baltic Sea, the North Sea, and the English Channel until 2040. Emission projections were calculated separately for every ship on annual basis, and the model took into account traffic growth, fleet renewal, and the forthcoming regulations. The regulation on sulfur content of ship fuels will drastically decrease the emissions of sulfur oxides and particulate matter $\left(\mathrm{PM}_{2.5}\right)$. As the regulation on nitrogen oxides $\left(\mathrm{NO}_{x}\right)$ only affects the new diesel engines, the decrease in emissions will be seen parallel with the fleet renewal. Globally internalized limits will turn $\mathrm{NO}_{x}$ emissions to decrease with moderate traffic growth. However, by designating the Baltic Sea and the North Sea as $\mathrm{NO}_{x}$ emission control areas, more drastic decrease would occur. $\mathrm{CO}_{2}$ emissions will stay almost constant through the studied timeline. Results show that European Commission's $\mathrm{CO}_{2}$ target for 2050 will not be reached without implementation of market based measures among the North Sea and the Baltic Sea fleets. Results present new information for decision makers to further develop international regulations of shipping especially in the Baltic Sea and the North Sea.
\end{abstract}

Keywords Greenhouse gas $\cdot$ Baltic Sea $\cdot$ North Sea $\cdot \mathrm{STEAM} \cdot \mathrm{PM}_{2.5}$

\section{Introduction}

Exhaust emissions of shipping are substantial, and they create problems as diminishing air quality and producing unwanted nutrient load on environment (Corbett et al. 2007;

\footnotetext{
J. Kalli $\cdot$ S. Repka $(\bowtie)$

Centre for Maritime Studies, University of Turku, P.O. Box 181, 28101 Pori, Finland

e-mail: sari.repka@utu.fi

J.-P. Jalkanen • L. Johansson

Finnish Meteorological Institute, P.O. Box 503, 00101 Helsinki, Finland
} 
Dalsøren et al. 2007; Endresen et al. 2003; Corbett et al. 1999; Capaldo et al. 1999; Wang et al. 2007; Georgakaki et al. 2005; Davis et al. 2001; Delft 2006; Kesgin and Vardar 2001; ENTEC 2002; Jalkanen et al. 2009, 2012a, b). Corbett et al. (2007) has estimated that 60,000 premature deaths globally can be contributed to shipping. In Europe, 49,500 deaths in 2000 were estimated to be related to shipping exhaust emissions, and the number of deaths were estimated rise to 53,400 in 2020 (Brandt et al. 2011). The increased concentrations of ultrafine particulate matter (PM) are the main reason for these mortality rates.

International Maritime Organization (IMO) agreed to reduce PM emissions of shipping by regulating the sulfur in ship fuels (IMO 2008). The Baltic Sea, the North Sea, and the English channel were designated as sulfur emission control area (SECA) with stringent limits for sulfur in ship fuels. Most of the sulfur in fuels (95-99\%) will be transformed to sulfur oxides $\left(\mathrm{SO}_{x}\right)$ after burning process whereas the rest is converted to particulate sulfate $\left(\mathrm{SO}_{4}\right)$, which is one of the key components of the PM. Gaseous $\mathrm{SO}_{2}$ can eventually be oxidized to $\mathrm{SO}_{3}$ and sulfuric acid. Therefore, the regulation is seen as an effective way to decrease the negative health effects of ship exhausts.

EC white paper (European Commission 2011) describes the $\mathrm{CO}_{2}$ targets for maritime transport. $\mathrm{CO}_{2}$ emissions should be cut by $40 \%$ (if feasible $50 \%$ ) by 2050 compared to 2005 levels. Target has been created according to the goal to limit global mean temperature rise to $2{ }^{\circ} \mathrm{C}$. IMO parties adopted mandatory measures in 2011 to reduce emissions of greenhouse gases (GHGs) from international shipping. The amendments to MARPOL Annex VI include measures to improve energy efficiency of ships. Mandatory Energy Efficiency Design Index will be applied only for new ships and the Ship Energy Efficiency Management Plan for all ships. There have also been discussions about market based measures (MBMs) to reduce GHGs of shipping in the IMO. Failure to reduce GHGs from maritime transport would negate efforts made in the other sectors.

Nitrogen oxides $\left(\mathrm{NO}_{x}\right)$ deposition from shipping contributes to eutrophication. Atmospheric deposition of nitrogen in total contributes to about $25-30 \%$ of nitrogen input to the Baltic Sea (EMEP 2006). It has been estimated that ship originated $\mathrm{NO}_{x}$ deposition can be over $50 \%$ of the total atmospheric deposition in some Baltic Sea areas and seasons (Stipa et al. 2007), but on annual average about $5 \%$ of the airborne nitrogen comes from shipping. MARPOL Annex VI (IMO 2008) includes a $\mathrm{NO}_{x}$ reduction scheme for new ships. Tier I and tier II limits are global and will be enforced on all new marine diesel engines. However, Tier III will affect only ships sailing inside specified $\mathrm{NO}_{x}$ Emission Control Areas (NECA). So far, only USA and Canadian coastal waters are proposed as NECA in the IMO. Possibility of proposing the Baltic Sea and North Sea are currently under investigation.

In order to further develop international regulation for exhaust emissions from shipping, we need to forecast the future development of the emissions based on the information on shipping and the forthcoming regulation that we have today. This paper presents future scenarios of ship originated atmospheric emissions $\left(\mathrm{CO}_{2}\right.$, $\mathrm{NO}_{x}, \mathrm{PM}$, and $\mathrm{SO}_{x}$ ) taking into account the forthcoming international regulations of sulfur in ship fuels and possible designation of the North Sea and the Baltic Sea as NECA. Scenarios include assumptions for traffic growth and efficiency increase of vessels. 


\section{Material and methods}

This study presents projections of ship originated atmospheric emissions until 2040. Calculation for scenarios was done with algorithm model programmed with Microsoft Excel. Base year for the future scenarios of the emissions from the North Sea and the Baltic Sea ship traffic was 2009. In 2009, however, the maritime transport was recovering from the economic recession and the emissions may actually be higher than projected in these calculations. Ship Traffic Emission Assessment Model (STEAM2) was used to evaluate the exhaust emissions of the maritime traffic based on the messages provided by the Automatic Identification System (AIS) which enables the identification and location determination of ships (Jalkanen et al. 2009, 2012a). However, only 13 ship types were included in the scenario calculations representing $85 \%$ of the total fuel consumption of shipping in the area. This fleet represents the commercial shipping, and the major part of the ship originated emissions. Categorization of ships was done according to IHS Fairplay (2011) which provides the ship database used in the STEAM2 model.

\subsection{Traffic growth}

The second GHG study by IMO (2009) addresses the transport demand as the most important driver for ship emissions. The study describes the correlation of gross domestic product (GDP) and maritime transport demand. Annual average growth in world GDP in the study varies between $2.7 \%$ (B2 scenario) and $3.9 \%$ (A1B scenario). Similarly, the total transport demand is estimated to vary from $0.9 \%$ (B2, low bound scenario) to $5.4 \%$ (A1T, high bound scenario). The transport demand also affects the efficiency of transport. When the freight markets change, the demand may increase or decrease. This will lead to shortage or surplus of ships correspondingly. Efficiency will decrease when demand is high and ships need to sail fast. Efficiency increases when there is more time for ships to sail leading to slow steaming. However, this type of change in market stability is difficult to include in the future scenarios and therefore left out of this study.

Algorithm estimating the emissions in this study applies to the growth rates presented in Table 1. Traffic growth is estimated to be moderate except for container traffic that is expected to be more intense. Two percentage higher growth rate for container ships is the same as estimated by the IMO (2009).

\subsection{Efficiency increase}

Speed is the key parameter with respect to fuel consumption of a ship and therefore to its emissions. Over time, there has been remarkable development in technology affecting efficiency and speed of ships. Switch from steam turbines to more efficient diesel engines, optimization of ship hull, and propulsion technology development are good examples of this. Technological development is still continuing, and estimates in efficiency increase have been presented by IMO (2009) for four ship types: tankers, general cargo, container, and bulk vessels (Fig. 1). Efficiency rates used in this study are iterated from the IMO (2009) data. Efficiency increase as percentage points per annum of different ship types are presented in Table 1. 
Table 1 Ship types of the studied North Sea and Baltic Sea fleet and their average lifetime, traffic growth rate, efficiency increase rate, and number of ships

\begin{tabular}{lllllc}
\hline \multicolumn{2}{l}{ Ship type } & $\begin{array}{l}\text { Average } \\
\text { lifetime (years) }\end{array}$ & $\begin{array}{l}\text { Traffic } \\
\text { growth (\%) }\end{array}$ & $\begin{array}{l}\text { Efficiency } \\
\text { increase (\%) }\end{array}$ & $\begin{array}{l}\text { Number of ships in the } \\
\text { European SECA fleet }\end{array}$ \\
\hline 1 & Reefer ship & 26 & 1.5 & 2.25 & 472 \\
2 & General cargo ship & 26 & 1.5 & 1.27 & 3,350 \\
3 & Product tanker & 26 & 1.5 & 1.90 & 530 \\
4 & Container ship & 25 & 3.5 & 2.25 & 1,466 \\
5 & Chemical tanker & 26 & 1.5 & 1.90 & 1,715 \\
6 & Crude oil tanker & 26 & 1.5 & 1.90 & 835 \\
7 & Liquid natural gas tanker & 29 & 1.5 & 1.90 & 61 \\
8 & Bulk ship & 26 & 1.5 & 1.90 & 2,316 \\
9 & Ro-ro ship & 27 & 1.5 & 2.25 & 273 \\
10 & ROPAX ship & 27 & 1.5 & 2.25 & 433 \\
11 & Vehicle carrier & 27 & 1.5 & 2.25 & 446 \\
12 & Liquid petroleum gas tanker & 26 & 1.5 & 1.90 & 266 \\
13 & Cruise ship & 27 & 1.5 & 2.25 & 127 \\
& TOTAL & & & & 12,290 \\
\hline
\end{tabular}

\subsection{Average lifetime of ships}

As $\mathrm{NO}_{x}$ regulations affect differently diesel engines depending their construction year (i.e., ship build year), fleet renewal rate is needed in estimation of $\mathrm{NO}_{x}$ emissions in the future. The algorithm utilizes the STEAM2 internal ship database and compares the

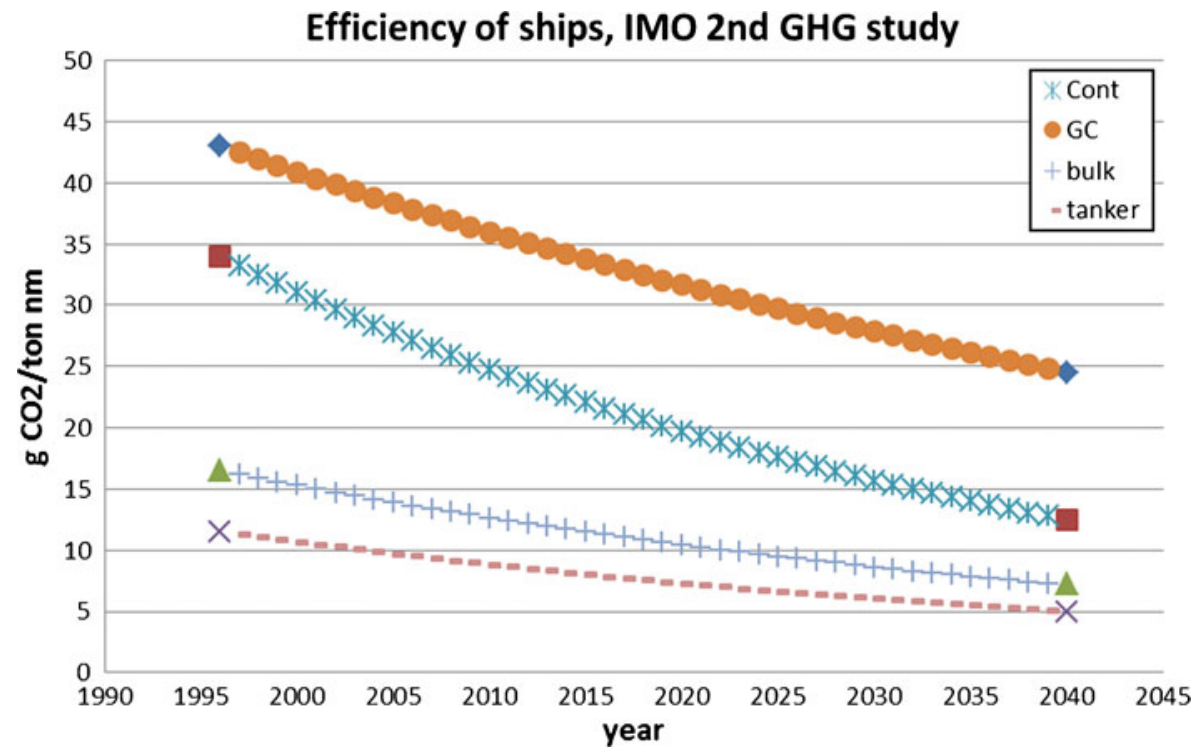

Fig. 1 Efficiency increase of four ship types (container, general cargo, bulk vessel, and tanker) as presented in the second IMO GHG study (IMO 2009) 
average lifetime of a ship to the build year of every ship in the Baltic fleet. Average lifetime is assumed separately for the 13 ship types of the study (Table 1).

\section{$2.4 \mathrm{CO}_{2}$ emissions}

The STEAM2 model estimates the fuel consumption of ships based on their movement (AIS) in the studied area. The second IMO GHG study (IMO 2009) presents a factor that can be used to convert heavy fuel oil (HFO) consumption to $\mathrm{CO}_{2}$ emissions (the factor is 3,130 for $\mathrm{HFO} \mathrm{kg}$ emitted/ton of fuel). In addition, an estimate for efficiency increase of most common ship types is presented in the study (Table 1, Fig. 1).

Traffic was assumed to increase according to Table 1. Assumptions for traffic growth and efficiency were utilized as annual percentages separately for each ship in the studied fleet. Projections were created until 2040.

Equations 1 and 2 present the logic of calculating the fuel consumption and $\mathrm{CO}_{2}$ emissions for a ship in particular year. Annual fuel consumption and emission inventories for the SECA fleet were created by summarizing the ship specific results.

Equation 1, estimating a fuel consumption of vessel $\mathrm{X}$ in year $\mathrm{a}+1$

Fuel consumption of vessel $\mathrm{X}$ in year $\mathrm{a}+1$ [tons] $=$ Fuel consumption of vessel $\mathrm{X}$ in year a [tons

$$
\begin{aligned}
& \times(1+\text { traffic increase of ship X }[\%] / 100 \%) \\
& \times(1-\text { efficiency increase of ship X }[\%] / 100 \%)
\end{aligned}
$$

Equation 2 shows conversion of fuel consumption into $\mathrm{CO}_{2}$ emissions

$\mathrm{CO}_{2}$ emissions of vessel $\mathrm{X}$ in year a [tons] $=3.130 \times$ fuel consumption of vessel $\mathrm{X}$ in year a[tons]

\section{$2.5 \mathrm{SO}_{x}$ emissions}

Almost all sulfur in ship fuel will oxidize to $\mathrm{SO}_{x}$ in the burning process of diesel engine, but a small fraction (1-5\%) will be emitted as particulate matter. Therefore, in order to estimate $\mathrm{SO}_{x}$ and $\mathrm{PM}$ emissions, we need to know the fuel consumption and the sulphur content of the fuel. STEAM2 model assumes that all main engines are using fuel with the maximum sulfur content allowed by the current legislation. In 2009, the maximum allowed sulphur content in ship fuels was $1.5 \mathrm{wt} \%$ (IMO 2008). The sulfur limit in SECA decreased to $1.0 \mathrm{wt} \%$ from January 7, 2010 onwards, and it will be further limited to $0.1 \mathrm{w} \%$ from January 1, 2015 onwards. The EU directive 2005/33/EC limited ship fuels at berth to $0.1 \mathrm{w} \%$ from January 1, 2010 onwards. Future scenarios take these decreasing limits into account. Auxiliary engine fuel sulfur content is $0.5 \%$ by default.

The base year 2009 emissions were estimated by the STEAM2 model. Some ships have voluntarily used low sulphur fuels for several years. STEAM2 utilizes a ship database developed for the model. Database includes data from IHS Fairplay, but supplements it with manually collected information about fuel qualities used in the ships, specific fuel oil consumption data obtained from engine manufacturers, other 
classification societies, experimentally determined emission factors, and installed abatement techniques. Therefore, the $\mathrm{SO}_{x}$ emissions produced by the model are more reliable than converting the $\mathrm{SO}_{x}$ emissions from the annual fuel consumption of the fleet. Calculation of future $\mathrm{SO}_{x}$ emissions are based on Eq. 1, except that the fuel consumption is replaced with the $\mathrm{SO}_{x}$ emissions of the ship (Eq. 3).

Equation 3, estimating $\mathrm{SO}_{x}$ emissions of vessel $\times$ in year $\mathrm{a}+1$

$$
\begin{gathered}
\mathrm{SO}_{\mathrm{x}} \text { emissions of vessel } \mathrm{X} \text { in year a }+1=\mathrm{SO}_{\mathrm{x}} \text { emissions of vessel } \mathrm{X} \text { in year a }[\text { tons }] \times \\
(1+\text { traffic increase of ship } \mathrm{X}[\%] / 100 \%) \times(1-\text { efficiency increase of ship } \mathrm{X}[\%] / 100 \%)
\end{gathered}
$$

The STEAM2 model estimates the $\mathrm{SO}_{x}$ emissions separately for the main and the auxiliary engines including assumptions for the sulfur content of the fuel. If a vessel is using $1.0 \% \mathrm{~S}$ fuel in main engines and $0.1 \% \mathrm{~S}$ in the auxiliaries in 2014 , the $\mathrm{SO}_{x}$ calculation follows the Eq. 4. $\mathrm{SO}_{x}$ emissions of the main engines are cut to one tenth due to the same sulfur content drop in the fuel. However, the factor for $\mathrm{SO}_{x}$ emissions of the auxiliaries is one because the fuel quality is not changing. $\mathrm{SO}_{x}$ emissions are practically linearly dependent on the sulfur content in the fuel.

Equation 4 shows an example of $0.1 \% \mathrm{~S}$ effect in 2015 when calculating the vessel's $\mathrm{SO}_{x}$ emissions. A vessel is assumed to use $1.0 \% \mathrm{~S}$ in main engines and $0.1 \%$ $\mathrm{S}$ in auxiliary engines in 2014.

$\mathrm{SO}_{\mathrm{x}}$ emissions of vessel $\mathrm{X}$ in year $2015=\mathrm{SO}_{\mathrm{x}}$ emissions of vessel $\mathrm{X}_{\text {main engines }}$ in year 2014 [tons] $\times$

$(1+$ traffic increase of ship X $[\%] / 100 \%) \times(1$-efficiency increase of ship X $[\%] / 100 \%) \times 0.1+$ $\mathrm{SO}_{\mathrm{x}}$ emissions of vessel $\mathrm{X}_{\text {auxiliaries }}$ in year 2014[tons] $\times(1+$ traffic increase of ship $\mathrm{X}[\%] / 100 \%) \times$

$(1-$ efficiencyincrease of ship X $[\%] / 100 \%) \times 1$

\subsection{Fine particle $\left(\mathrm{PM}_{2.5}\right)$ emissions}

In STEAM2 model (Jalkanen et al. 2012a), $\mathrm{PM}_{2.5}$ emissions are divided into elementary carbon (EC), organic carbon, ash, sulfate $\left(\mathrm{SO}_{4}\right)$, and associated water $\left(\mathrm{H}_{2} \mathrm{O}\right)$. These five components together represent the PM emissions in the scenarios of this paper. PM emissions are highly dependent on the fuel quality and the engine load (Buhaug et al. 2009; Agrawal et al. 2008) (Fig. 2). STEAM2 model takes these into account in the year 2009 PM emissions, but does not include the load dependent conversion efficiency of fuel sulfur to $\mathrm{SO}_{4}$ as described by Petzold et al. (2010). According to Petzold et al. (2010), the conversion of fuel sulfur to $\mathrm{PM} \mathrm{SO}_{4}$ increases with increasing engine load (from 1 to $5 \%$ ), which is not currently taken into account in the STEAM2 model. However, when creating future scenarios and utilizing percentile changes per annum, we assume that the nature of traffic will remain constant and changes concerning engine load are not included in the calculations. PM scenarios of this paper take into account the effect of sulfur in ship fuels as described in IMO (2009) and as presented in Fig. 2 and Table 2.

Equation 3 was used also for the PM calculations. Conversion factors (Table 2) were used with fuel quality changes. For example, a ship using heavy fuel oil of 


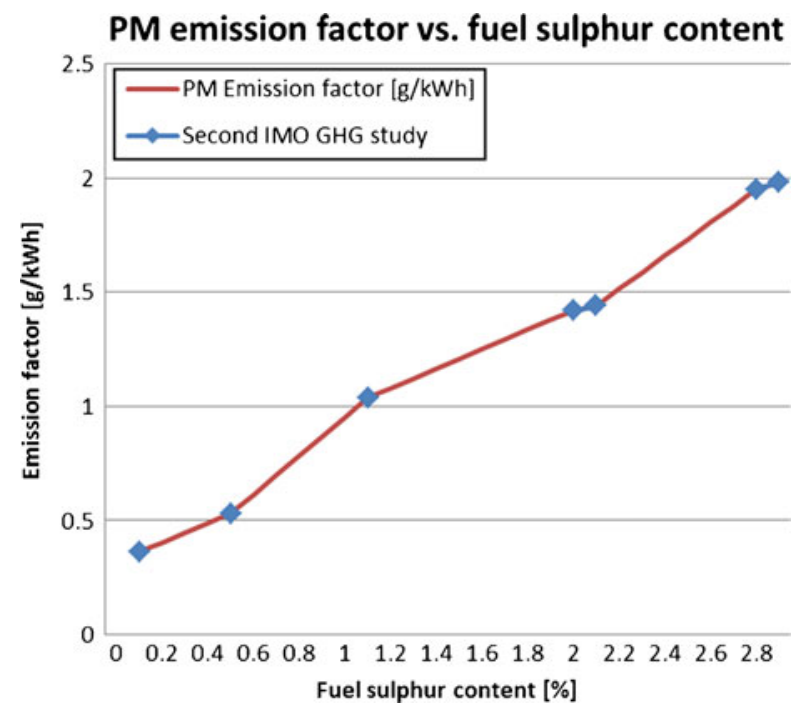

Fig. 2 Change of $\mathrm{PM}_{2.5}$ emission factor $[\mathrm{g} / \mathrm{kWh}]$ as the function of sulfur content in ship fuels as presented by Buhaug et al. 2009 in the Second IMO GHG study

$1.0 \% \mathrm{~S}$ in the main engines in 2014 will have to start using fuel oil with $0.1 \% \mathrm{~S}$ in 2015. Then, its $\mathrm{PM}_{2.5}$ emissions from the main engines will be multiplied with a factor 0.38 in addition with percentile changes of traffic growth and efficiency increase (Eq. 5). If it was assumed that the ship was already using $0.1 \% \mathrm{~S}$ in the main or auxiliary engines, the $\mathrm{PM}_{2.5}$ emissions will have a conversion factor of one.

Equation 5 shows the effect of switching to $0.1 \% \mathrm{~S}$ fuel in 2015 for $\mathrm{SO}_{x}$ emissions. A vessel is assumed to use $1.0 \% \mathrm{~S}$ fuel in main engines and $0.1 \% \mathrm{~S}$ in auxiliary engines in 2014.

$\mathrm{PM}_{2.5}$ emissions of vessel $\mathrm{X}$ in year $2015=\mathrm{PM}_{2.5}$ emissions of vessel $\mathrm{X}_{\text {main engines }}$ in year 2014 [tons] $\times$ $(1+$ traffic increase of ship X $[\%] / 100 \%) \times(1-$ efficiency increase of ship X $[\%] / 100 \%) \times 0.38+$ PM2.5 emissions of vessel X auxiliaries in year 2014 [tons] $\times(1+$ traffic increase of ship X [\%] $/ 100 \%)$ $\times(1-$ efficiency increase of ship X $[\%] / 100 \%) \times 1$

Table 2 Conversion factor for $\mathrm{PM}_{2.5}$ in different cases of fuel quality change

\begin{tabular}{ll}
\hline Fuel quality change & $\mathrm{PM}_{2.5}$ conversion factor \\
\hline $1.5 \mathrm{~S} \%$ to $1.0 \mathrm{~S} \%$ & 0.79 \\
$1.0 \mathrm{~S} \%$ to $0.1 \mathrm{~S} \%$ & 0.38 \\
$1.5 \mathrm{~S} \%$ to $0.1 \mathrm{~S} \%$ & 0.30 \\
$0.5 \mathrm{~S} \%$ to $0.1 \mathrm{~S} \%$ & 0.68 \\
$1.5 \mathrm{~S} \%$ to $0.5 \mathrm{~S} \%$ & 0.44 \\
$1.0 \mathrm{~S} \%$ to $0.5 \mathrm{~S} \%$ & 0.56
\end{tabular}




\section{7 $\mathrm{NO}_{x}$ emissions}

Because the regulations concerning $\mathrm{NO}_{x}$ emissions will affect ships built after a specific date, age of a ship and fleet renewal rate must be known and defined when defining future scenarios. Age of a ship is included in the STEAM2 internal ship database and can be used in scenario calculations. Renewal rate is an assumption made for the scenario calculations of this paper, and it is utilized as an average ship lifetime. Average ship lifetimes are presented in Table 1 and given separately for each studied ship type.

STEAM2 model assumes that all ships in 2009 were following the tier I standard. Illustration of the IMO's three tier scheme is presented in Fig. 3. Projection calculation assumes that when a ship reaches an average maximum lifetime of its category, it will be replaced with an otherwise similar ship (size, type, engines, fuel consumption, emissions, etc.) except that it is complying the current regulation valid in that year. For example, if a ship will be replaced in 2013, its $\mathrm{NO}_{x}$ emissions of 2012 will be multiplied with traffic growth and efficiency increase factors and in addition with the tier II factor of $20 \%$ from the tier I level.

Equation 6 shows an example of estimating year $2013 \mathrm{NO}_{x}$ emissions for a new vessel $\mathrm{x}$. A tier I vessel by reaching its maximum lifetime is replaced by new tier II vessel.

$\mathrm{NO}_{\mathrm{x}}$ emissions of vessel $\mathrm{X}$ in year $2013=\mathrm{NO}_{\mathrm{x}}$ emissions of vessel in year 2012 [tons] $\times(1+$ traffic increase of ship X $[\%] / 100 \%) \times(1-$ efficiency increase of ship X [\%]/100\%) $\times[(100 \%+$ Tier II factor $(-20 \%)) / 100 \%]$

There are two $\mathrm{NO}_{x}$ projections produced to investigate the effect of possible designation of the Baltic Sea and the North Sea as NECA. In the NECA scenario ships renewed after January 1, 2016 will be assumed to be tier III compliant.

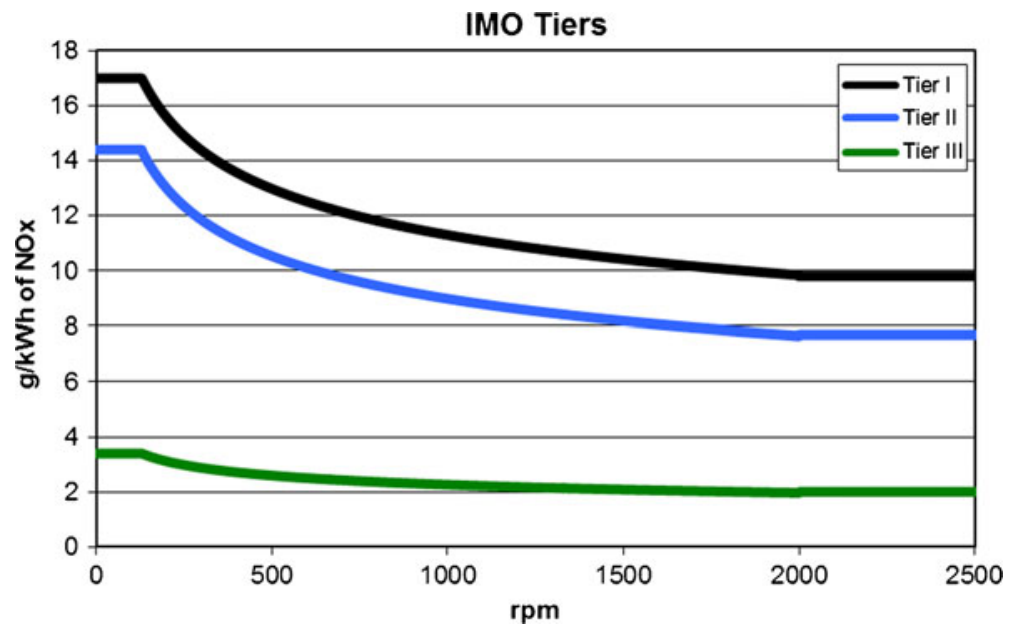

Fig. 3 Three tier scheme of IMO for $\mathrm{NO}_{x}$ emissions of diesel engines. Tier II represents $20 \%$ decrease from the tier I level and tier III $80 \%$ decrease from the tier I level 
Traffic growth and efficiency increase in the $\mathrm{NO}_{x}$ scenarios are inferred from the $\mathrm{NO}_{x}$ emissions of current year fleet. In other words, the traffic growth include as much tier I, II, and III traffic as in the current fleet. This assumption does not take into account the possibility that traffic increase can result from ships with varying age arriving to the NECA area.

2.8 European SECA fleet and its emissions in the base year 2009

Table 3 presents the emission inventory for the total European SECA fleet in 2009 and that of the fleet chosen for this study. We can see how filtrating smaller ship types out decrease the emissions (Table 3). Number of ships in the studied European SECA commercial fleet per ship type is presented in Table 1.

\section{Results}

\section{1 $\mathrm{CO}_{2}$ emissions}

According to the projections, $\mathrm{CO}_{2}$ emissions stay almost constant until 2040 (Fig. 4). It can be seen how efficiency increase is overriding the traffic growth rate preventing $\mathrm{CO}_{2}$ emissions to increase.

Highest fuel consumption and therefore $\mathrm{CO}_{2}$ emissions are produced by container, ROPAX, and general cargo vessels (Table 4). Container and general cargo vessels are the only ship types of which $\mathrm{CO}_{2}$ emissions continue to grow in the future. Reason for this is the higher traffic growth rate of container vessels and smaller efficiency increase rate of general cargo vessels compared to other ship types.

Table 3 Comparison of base year (2009) emissions of total European SECA fleet (STEAM2) and European SECA commercial fleet (13 ship types of this study, all identified by their IMO number). Total fleet includes all ships equipped with an AIS transponder but not necessarily an IMO number, i.e., ice breakers, tugs, barges, yachts, etc.

\begin{tabular}{llll}
\hline & TOTAL 2009 & $\begin{array}{l}\text { This study 2009, commercial } \\
\text { fleet, 13 ship types all identified } \\
\text { by their IMO number }\end{array}$ & Difference, \% \\
\hline Fuel consumption [megatons] & 15.3 & 13.0 & -15 \\
$\mathrm{CO}_{2}$ [megatons] & 47.3 & 40.8 & -14 \\
$\mathrm{NO}_{x}$ [kilotons] & 1003 & 878 & -12 \\
$\mathrm{SO}_{x}$ [kilotons] & 332 & 278 & -16 \\
$\mathrm{PM}_{2.5}$ [kilotons] & 76.5 & 64.5 & -16 \\
Number of ships & $31,407^{\mathrm{a}}(21,038)^{\mathrm{b}}$ & 12,290 & $-61^{\mathrm{a}}(-42)^{\mathrm{b}}$ \\
\hline
\end{tabular}

The number of ships in parenthesis represents the vessels with an IMO number. Thus, the difference of $-61 \%$ represents the difference in number of ships between the commercial fleet and all vessels regardless of their size

${ }^{a}$ Including the small vessels with no IMO number

${ }^{\mathrm{b}}$ Excluding the small vessels with no IMO number 


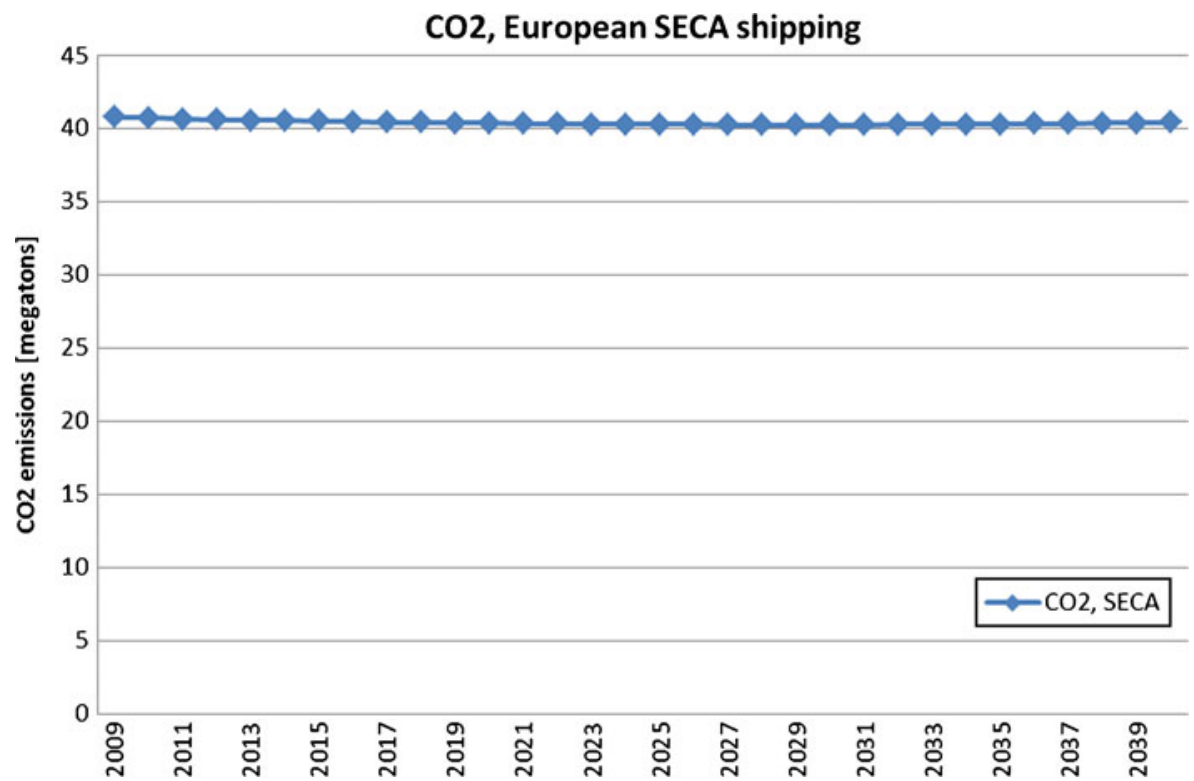

Fig. $4 \mathrm{CO}_{2}$ emissions of the European SECA commercial fleet until 2040

\section{$3.2 \mathrm{SO}_{x}$ emissions}

$\mathrm{SO}_{x}$ emissions will decrease step by step (Fig. 5) when the regulation on sulphur in ship fuels enters into force. The first drop can be seen in 2010 when sulphur limit drops from 1.5 to $1.0 \%$ as described in IMO (2008). At the same time, EU directive 2005/33/EC on sulfur in ship fuels at berth enters into force also affecting the results

Table 4 Estimated $\mathrm{CO}_{2}$ emissions [kilotons] of different ship types until 2015

\begin{tabular}{llllllll}
\hline & 2009 & 2010 & 2011 & 2012 & 2013 & 2014 & 2015 \\
\hline Crude oil tanker & 2,779 & 2,761 & 2,743 & 2,732 & 2,720 & 2,708 & 2,697 \\
LPG tanker & 689 & 685 & 681 & 678 & 675 & 672 & 669 \\
Chemical tanker & 4,348 & 4,320 & 4,292 & 4,274 & 4,255 & 4,237 & 4,219 \\
Product tanker & 1,196 & 1,188 & 1,180 & 1,175 & 1,170 & 1,165 & 1,160 \\
Bulk ship & 2,518 & 2,502 & 2,486 & 2,475 & 2,465 & 2,454 & 2,444 \\
Container & 9,102 & 9,264 & 9,426 & 9,536 & 9,648 & 9,761 & 9,875 \\
LNG tanker & 114 & 114 & 113 & 112 & 112 & 111 & 111 \\
Ropax & 8,237 & 8,141 & 8,045 & 7,982 & 7,919 & 7,857 & 7,795 \\
Ro-ro & 3,408 & 3,368 & 3,328 & 3,302 & 3,276 & 3,250 & 3,225 \\
Vehicle carrier & 1,274 & 1,259 & 1,244 & 1,234 & 1,224 & 1,215 & 1,205 \\
General cargo & 5,032 & 5,048 & 5,064 & 5,074 & 5,085 & 5,096 & 5,106 \\
Cruise ship & 1,159 & 1,145 & 1,132 & 1,123 & 1,114 & 1,105 & 1,097 \\
Reefer & 958 & 947 & 935 & 928 & 921 & 914 & 906 \\
\hline
\end{tabular}


SOx and PM2.5 of commercial shipping, European SECA

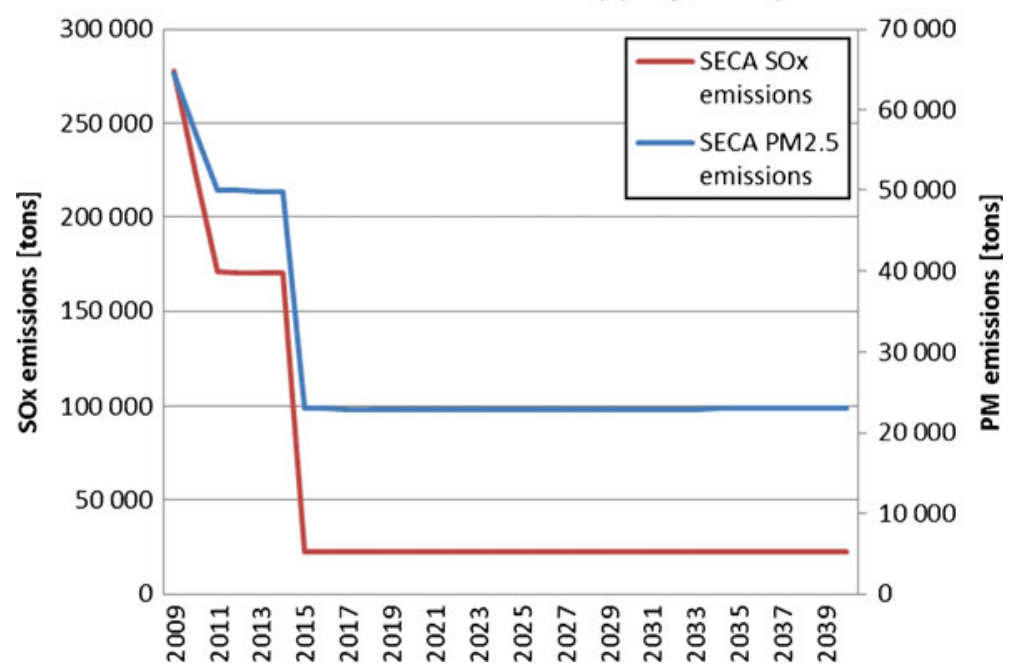

Fig. $5 \mathrm{SO}_{x}$ and $\mathrm{PM}_{2.5}$. emissions of the European SECA commercial fleet until 2040

even if its effect is minor compared to Marpol Annex VI regulation. $\mathrm{SO}_{x}$ and $\mathrm{PM}_{2.5}$ emissions stay almost constant after 2015 until 2040, and they are both at the same level (around $23 \mathrm{kt} /$ year).

Year 2011 is the first full calendar year when we can see the real effect of the $1.0 \%$ S limit. $\mathrm{SO}_{x}$ emissions will drop $39 \%$ in 2011 from the 2009 level and $87 \%$ in 2015 from the 2014 level as the ships are assumed to switch from $1.0 \mathrm{~S} \%$ fuel to $0.1 \mathrm{~S} \%$. The total decrease is $92 \%$ in 2015 from the 2009 level (Table 5).

Container and ROPAX vessels were the ship types with the highest $\mathrm{SO}_{x}$ emissions in 2009 (Table 6). They produced $43 \%$ of emissions even though they represent only $15 \%$ of the fleet. This is because their traffic amount and fuel consumption in the area is high. General cargo vessels, chemical tankers, and ro-ro vessels were three next highest $\mathrm{SO}_{x}$ emitters.

\section{3 $\mathrm{PM}_{2.5}$ emissions}

$\mathrm{PM}_{2.5}$ emissions are decreasing in similar fashion as $\mathrm{SO}_{x}$ emissions, but not as drastically (Fig. 5). This is due to the fact that there will still be PM emissions even

Table 5 Effect of MARPOL Annex VI to $\mathrm{SO}_{\mathrm{x}}$ and $\mathrm{PM}_{2.5}$ emissions (\%)

\begin{tabular}{lccc}
\hline Pollutant & Decrease between 2009 and 2011 & $\begin{array}{c}\text { Decrease between } \\
2014 \text { and } 2015\end{array}$ & $\begin{array}{l}\text { Total decrease } \\
\text { between } 2009 \\
\text { and } 2015\end{array}$ \\
\hline $\begin{array}{c}\text { Change in sulphur content } \\
\text { of ship fuels inside SECA }\end{array}$ & $\begin{array}{c}1.5 \% \mathrm{~S} \text { to } 1.0 \% \mathrm{~S} \text { (including } \\
0.1 \% \mathrm{~S} \text { at berth in Baltic/EU ports) }\end{array}$ & 1.0 to $0.1 \% \mathrm{~S}$ & 1.5 to $0.1 \% \mathrm{~S}$ \\
$\mathrm{SO}_{x}$ & $-39 \%$ & $-87 \%$ & $-92 \%$ \\
$\mathrm{PM}_{2.5}$ & $-23 \%$ & $-54 \%$ & $-64 \%$ \\
\hline
\end{tabular}


Table 6 Estimated $\mathrm{SO}_{x}$ emissions of different ship types [ton] until 2015

\begin{tabular}{llllllll}
\hline & 2009 & 2010 & 2011 & 2012 & 2013 & 2014 & 2015 \\
\hline Crude oil tanker & 18,428 & 14,754 & 11,397 & 11,348 & 11,299 & 11,251 & 1,375 \\
LPG tanker & 4,155 & 3,279 & 2,466 & 2,456 & 2,445 & 2,435 & 340 \\
Chemical tanker & 27,792 & 21,986 & 16,605 & 16,534 & 16,463 & 16,392 & 2,245 \\
Product tanker & 7,604 & 6,017 & 4,546 & 4,526 & 4,507 & 4,488 & 616 \\
Bulk ship & 17,310 & 13,748 & 10,465 & 10,420 & 10,375 & 10,331 & 1,361 \\
Container & 62,793 & 51,196 & 38,987 & 39,443 & 39,905 & 40,373 & 5,492 \\
LNG tanker & 758 & 614 & 483 & 481 & 479 & 477 & 52 \\
Ropax & 58,461 & 46,810 & 36,452 & 36,166 & 35,882 & 35,601 & 4,582 \\
Ro-ro & 24,940 & 20,081 & 15,764 & 15,640 & 15,518 & 15,396 & 1,894 \\
Vehicle carrier & 9,165 & 7,292 & 5,632 & 5,587 & 5,544 & 5,500 & 668 \\
General cargo & 31,650 & 25,127 & 18,737 & 18,776 & 18,816 & 18,856 & 2,774 \\
Cruise ship & 8,951 & 7,212 & 5,632 & 5,588 & 5,544 & 5,500 & 615 \\
Reefer & 5,945 & 4,683 & 3,547 & 3,520 & 3,492 & 3,465 & 463 \\
\hline
\end{tabular}

if the fuel would be completely sulfur free. $\mathrm{PM}_{2.5}$ emissions will drop $23 \%$ in 2011 from the 2009 level and $54 \%$ in 2015 from 2014 level. The total decrease is $64 \%$ in 2015 from the 2009 level (Table 5). Division of $\mathrm{PM}_{2.5}$ emissions between ship types is very similar compared to the $\mathrm{SO}_{x}$ emissions (Table 7).

\section{4 $\mathrm{NO}_{x}$ emissions}

Two scenarios were developed for $\mathrm{NO}_{x}$ emissions. Scenario 1 is calculated assuming designation of the Baltic Sea, North Sea, and English channel as NECA (Fig. 6).

Table 7 Estimated $\mathrm{PM}_{2.5}$ emissions [ton] of different ship types until 2015

\begin{tabular}{llllllll}
\hline & 2009 & 2010 & 2011 & 2012 & 2013 & 2014 & 2015 \\
\hline Crude oil tanker & 4,447 & 3,909 & 3,429 & 3,414 & 3,399 & 3,385 & 1,480 \\
LPG tanker & 1,087 & 952 & 830 & 826 & 823 & 819 & 390 \\
Chemical tanker & 6,729 & 5,899 & 5,148 & 5,126 & 5,104 & 5,082 & 2,391 \\
Product tanker & 1,845 & 1,617 & 1,411 & 1,405 & 1,399 & 1,393 & 660 \\
Bulk ship & 4,098 & 3,596 & 3,145 & 3,131 & 3,118 & 3,104 & 1,419 \\
Container & 15,383 & 13,899 & 12,171 & 12,313 & 12,457 & 12,603 & 5,917 \\
LNG tanker & 203 & 179 & 158 & 157 & 156 & 156 & 63 \\
Ropax & 12,557 & 11,019 & 9,722 & 9,646 & 9,570 & 9,495 & 4,346 \\
Ro-ro & 5,392 & 4,725 & 4,165 & 4,132 & 4,100 & 4,067 & 1,773 \\
Vehicle carrier & 2,167 & 1,892 & 1,660 & 1,647 & 1,634 & 1,621 & 703 \\
General cargo & 7,329 & 6,488 & 5,649 & 5,661 & 5,673 & 5,685 & 2,806 \\
Cruise ship & 1,862 & 1,633 & 1,434 & 1,423 & 1,412 & 1,401 & 578 \\
Reefer & 1,419 & 1,236 & 1,080 & 1,071 & 1,063 & 1,055 & 485 \\
\hline
\end{tabular}




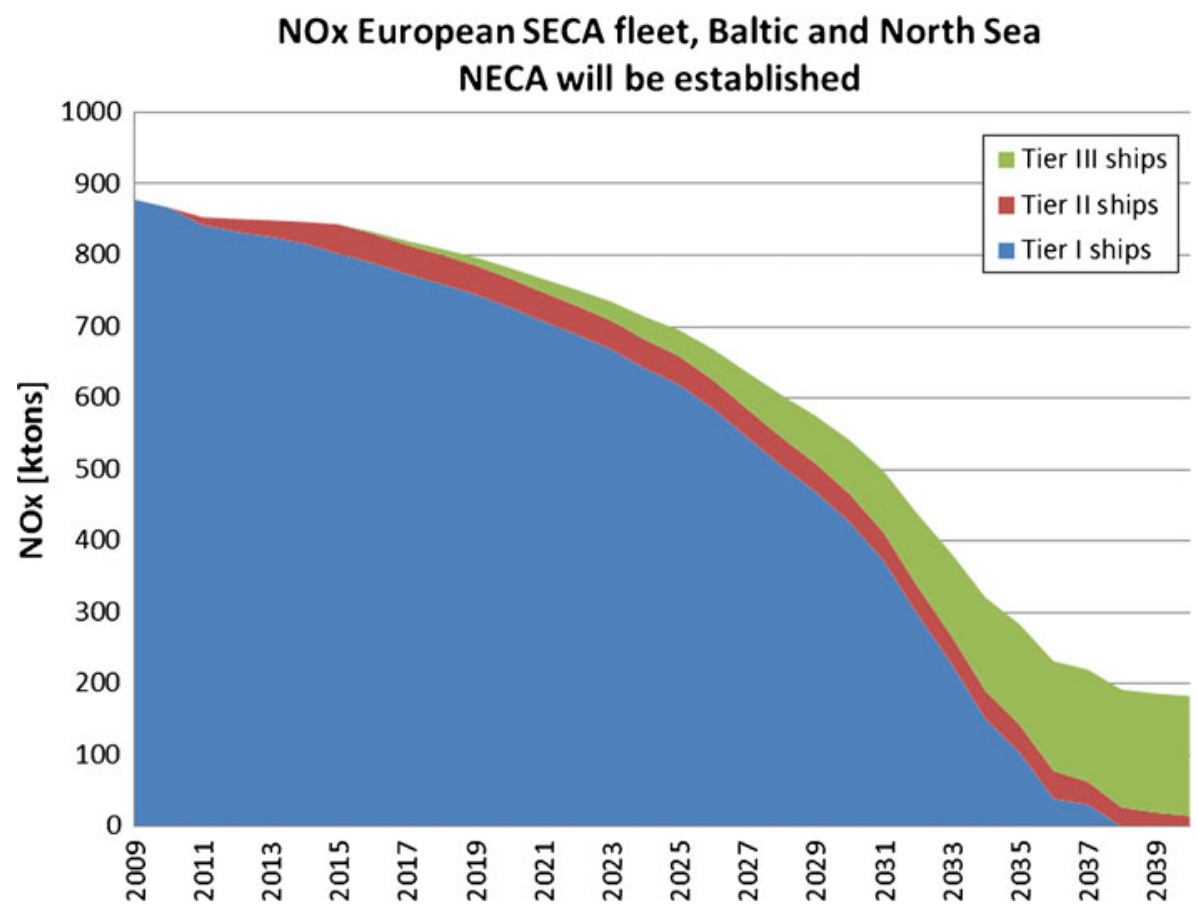

Fig. 6 Scenario 1. $\mathrm{NO}_{x}$ emissions of the European SECA commercial fleet until 2040. Emissions are presented as they are produced by tier I, tier II, and tier III ships

Emissions were estimated to drop $11 \%$ in 2020 and $79 \%$ in 2040 compared to base year 2009 (Table 8).

Scenario 2 presents estimations for $\mathrm{NO}_{x}$ if the Baltic Sea, North Sea, and English channel NECA will not be established (Fig. 7). Emissions in this case were estimated to decrease $6 \%$ in 2020 and $22 \%$ in 2040 compared to base year 2009 (Table 8).

Figures 6 and 7 present the share of $\mathrm{NO}_{x}$ emissions produced by tier I, tier II, and tier III ships in scenario 1 and scenario 2, respectively. Figures show how tier I ships will be removed from the fleet before 2037 .

Table $8 \mathrm{NO}_{x}$ emissions of the Baltic commercial fleet in 2009, 2020, and 2040 and their estimated decrease (\%) compared to base year 2009. Scenario 1: Baltic Sea will be designed as NECA. Scenario 2: Baltic NECA will not be established

\begin{tabular}{|c|c|c|c|c|c|}
\hline $\begin{array}{l}\mathrm{NO}_{x} \text { emission of the } \\
\text { Baltic commercial fleet }\end{array}$ & 2009 & \multicolumn{2}{|c|}{$\begin{array}{l}2020, \text { decrease } \\
\text { from } 2009 \text { level }\end{array}$} & \multicolumn{2}{|c|}{$\begin{array}{l}2040, \text { decrease } \\
\text { from } 2009 \text { level }\end{array}$} \\
\hline $\begin{array}{l}\text { Scenario 1, Baltic and } \\
\text { North Sea NECA }\end{array}$ & $878 \mathrm{kt}$ & $783 \mathrm{kt}$ & $-11 \%$ & $183 \mathrm{kt}$ & $-79 \%$ \\
\hline $\begin{array}{l}\text { Scenario 2, no Baltic and } \\
\text { North Sea NECA }\end{array}$ & $878 \mathrm{kt}$ & $827 \mathrm{kt}$ & $-6 \%$ & $686 \mathrm{kt}$ & $-22 \%$ \\
\hline
\end{tabular}




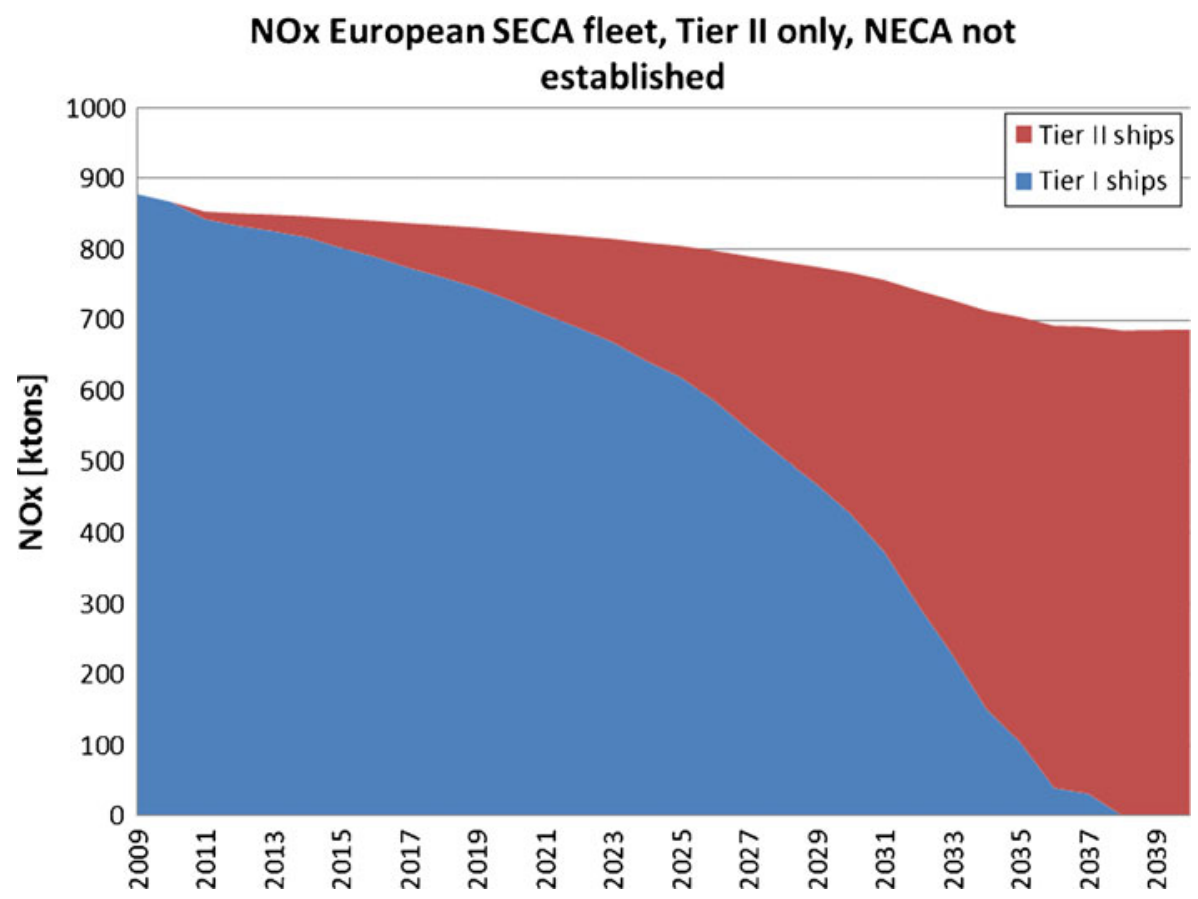

Fig. 7 Scenario 2. $\mathrm{NO}_{x}$ emissions of the European SECA commercial fleet until 2040. Emissions presented as they are produced by tier I and tier II ships

\section{Conclusions}

MARPOL Annex VI regulating the sulfur in ship fuels is an efficient method to decrease $\mathrm{SO}_{x}$ and $\mathrm{PM}_{2.5}$ emissions of shipping. Especially in the case of European SECA, a drastic decrease of $\mathrm{SO}_{x}$ and $\mathrm{PM}_{2.5}(92 \%$ and $64 \%$, respectively, from the 2009 level) in 2015 will occur. However, the cost of the fuel switch may be high; our most recent estimate is in the range of 3.3-4.6 billion USD per year (Jalkanen et al. 2012b).

Ship originated $\mathrm{NO}_{x}$ emissions will turn to slow decrease due to MARPOL Annex VI's three tier reduction scheme. This will happen even if the Baltic Sea, North Sea, and English channel would not be designated as $\mathrm{NO}_{x}$ Emission Control Area. Results show how the efficiency increase, and tier II $\mathrm{NO}_{x}$ limit together outweigh the moderate traffic growth. $\mathrm{NO}_{x}$ emissions are estimated to decrease $6 \%$ in 2020 and $22 \%$ in 2040 from the 2009 level. If the Baltic Sea, North Sea, and English channel will be designated as $\mathrm{NO}_{x}$ Emission Control Area, more drastic decrease in $\mathrm{NO}_{x}$ emissions will occur. $\mathrm{NO}_{x}$ emissions are estimated to decrease $11 \%$ in 2020 and $79 \%$ in 2040 from the 2009 level.

Container vessels, different tankers, ro-ro/passenger and general cargo ships are generating the most of ship originated atmospheric emissions in the SECA areas. Even if the number of container, RoPax, and ro-ro vessels is low compared to other ship types, they represent the major share of the total fuel consumption in the area.

$\mathrm{CO}_{2}$ emissions of the European SECA commercial fleet will stay almost constant in the future if the moderate traffic growth and efficiency increase assumptions used in this study will come true. Container and general cargo vessels are the only ship 
types the $\mathrm{CO}_{2}$ emissions of which continue to grow in the future. The reason for this is the higher traffic growth rate of container vessels and smaller efficiency increase rate of general cargo vessels compared to other ship types.

EC white paper (European Commission 2011) describes the $\mathrm{CO}_{2}$ targets for maritime transport. $\mathrm{CO}_{2}$ emissions from maritime transport should be cut by $40 \%$ (if feasible $50 \%$ ) by 2050 compared to 2005 levels. The white paper does not define a fleet or an area for the target, but from the results of this study, we can see that the Baltic Sea and the North Sea will not be able to reach this target with the current policies.

There are several methods how $\mathrm{CO}_{2}$ emissions can be cut. Technical methods have been taken into account in this study by the assumption of efficiency increase. Liquiefied natural gas (LNG) and other alternative fuels are a long-term solution for both $\mathrm{CO}_{2}$ and $\mathrm{NO}_{x}$ emissions and therefore probably will not alone lead to reaching of the EC targets.

Slow steaming can remarkably reduce fuel consumption of specific ships. According to Cariou (2011), slow steaming has reduced emissions by approximately $11 \%$ over the past 2 years. In containerships, up to $70 \%$ decrease in emissions can be achieved when the speed is halved (Corbett et al. 2009). Multiengine vessels are able to shut down engines when reducing their speed, but for ships with one main engine, it would mean lowering of the engine load. This can lead to increase of $\mathrm{PM}$ and $\mathrm{NO}_{x}$ emissions and higher specific fuel consumption because the engine is not running on its optimal engine load. Larger number of ships is also needed to reach the same annual cargo turnover as without the slow steaming. This will increase the need for additional container capacity because the rotation of cargo containers will also slow down. There is overcapacity of ships in the market in time of economic recession which leads to slow steaming of ships. When additional ships are added to maintain scheduled frequency, lower speeds still provide $\mathrm{CO}_{2}$ reduction on most routes, although cost efficiency varies among routes (Corbett et al. 2009). The base year 2009 of this study could be an example of it. According to Cariou (2011), slow steaming is sustainable in the long run only if the bunker prices remain rather high $(\$ 350-400)$ or if powerful market-based solutions are implemented to sustain bunker prices.

Currently, there is a debate in IMO about the MBMs. Some of the presented MBMs have an out of sector influences. The Global Emission Trading System and the International Fund for GHG emissions include out of sector reductions mechanisms and a possibility to compensate the $\mathrm{CO}_{2}$ emissions. Based on the results of this study, we can conclude that without implementation of new mechanisms to reduce $\mathrm{CO}_{2}$ emissions, i.e., the market based measures, the EC target for the year 2050 will not be reached.

The newest emission estimates show a $9 \%$ increase in $\mathrm{CO}_{2}$ emissions between 2009 and 2010 as the maritime transport is recovering from the economic recession. Therefore, the emissions may even be higher than projected because year 2009 may not represent a normal year of traffic activity in the area. In future studies, it would be advisable to change the base year to 2010 or 2011 and to include an estimate of market penetration of LNG as ship fuel to improve the precision of emission projections.

Acknowledgments We gratefully acknowledge the support of the Finnish Transport Safety Agency (TraFi) and the member states of the Marine Environment Protection Committee of the Baltic Sea (Helcom) in this work. The research leading to these results has received funding from the European Regional Development Fund, Central Baltic INTERREG IV A program within the project SNOOP. The publication has been partly produced in cooperation with the BSR InnoShip project (project no. 051 in the grant contract). The project is partly financed by the EU Baltic Sea Region Program 2007-2013, which supports transnational cooperation in 
the Baltic Sea region. This publication reflects the author's views and the Managing Authority of Central Baltic INTERREG IV A program 2007-2013 cannot be held liable for the information published by project partners. This publication cannot be taken to reflect the views of the European Union.

Open Access This article is distributed under the terms of the Creative Commons Attribution License which permits any use, distribution, and reproduction in any medium, provided the original author(s) and the source are credited.

\section{References}

Agrawal H, Welch WA, Miller JW, Cocker DR (2008) Emission measurements from a crude oil tanker at sea. Environ Sci Tech 42:7098-7103. doi:10.1021/es703102y

Brandt J, Silver JD, Christensen JH, Andersen M S, Bønløkke JH, Sigsgaard T, Geels C, Gross A, Hansen AB, Hansen KM, Hedegaard GB, Kaas E, Frohn LM (2011) Assessment of Health-Cost Externalities of Air Pollution at the National Level using the EVA Model System. CEEH Scientific Report No 3, Centre for Energy, Environment and Health Report series, March 2011, pp. 98. http://www.ceeh.dk/ CEEH Reports/Report 3/CEEH Scientific Report3.pdf. Accessed 14 Mar 2012

Buhaug Ø, Corbett JJ, Endresen Ø, Eyring V, Faber J, Hanayama S, Lee DS, Lee D, Lindstad H, Markowska AZ, Mjelde A, Nelissen D, Nilsen J, Pålsson C, Winebrake JJ, Wu W-Q, Yoshida K (2009) Second IMO GHG study 2009. International Maritime Organization (IMO) London, UK

Capaldo K, Corbett JJ, Kasibhatla P, Fischbeck P, Pandis SN (1999) Effects of ship emissions on sulphur cycling and radiative climate forcing over the ocean. Nature 400:743-746

Cariou P (2011) Is slow steaming sustainable means of reducing $\mathrm{CO}_{2}$ emissions from container shipping. Tranport Res Part D 16:260-264. doi:10.1016/j.trd.2010.12.005

Corbett J, Fischbeck P, Pandis S (1999) Global nitrogen and sulfur inventories for oceangoing ship. J Geophys Res 104:3457-3470

Corbett JJ, Winebrake JJ, Green EH, Kasibhatla P, Eyring V, Lauer A (2007) Mortality from ship emissions: a global assessment. Env Sci Tech 41:8512. doi:10.1021/es071686z

Corbett JJ, Wang H, Winebrake JJ (2009) The effectiveness and costs of speed reduction on emissions from international shipping. Transport Res Part D 14:593-598. doi:10.106/j.trd.2009.08.005

Dalsøren SB, Endresen Ø, Isaksen ISA, Gravir G, Sørgård E (2007) Environmental impacts of the expected increase in sea transportation, with a particular focus on oil and gas scenarios for Norway and northwest Russia. J Geophys Res 112, D02310. doi:10.1029/2005JD006927

Davis DD, Grodzinsky G, Kasibhatla P, Crawford J, Chen G, Liu S, Bandy A, Thornton D, Guan H, Sandholm S (2001) Impact of ship emissions on marine boundary layer NOx and SO2 distributions over the pacific basin. Geophys Res Lett 28:235-238

Delft CE (2006) Greenhouse Gas Emissions for Shipping and Implementation Guidance for the Marine Fuel Sulphur Directive. Germanischer Lloyd, The Netherlands

Endresen Ø, Sørgard E, Sundet JK, Dalsøren SB, Isaksen ISA, Berglen TF, Gravir G (2003) Emission from international sea transportation and environmental impact. J Geophys Res 108(D17):4560. doi:10.1029/ 2002JD002898

EMEP expert emissions. (2006) available at: http://webdab1.umweltbundesamt.at/cgi-bin/ wedb 2 controller.pl?State $=$ scaled $\&$ countries $=\% 3$ ASHIPS $\&$ years $=2006 \&$ sectors $=1008 \&$ pollutants $=$ SOx\&datatype=nationalhtml\&horizontal=area\&vertical=year\&info=on. Accessed 20 Mar 2012

ENTEC UK Limited (2002). Quantification of emissions from ships associated with ship movements between ports in the European Community. Final report to the European Commission, London UK

Commission E (2011) Roadmap to a single European transport area-towards a competitive and resource efficient transport system. White paper, Brussels, 28.3.2011

Georgakaki A, Coffey RA, Lock G, Sorenson SC (2005) Transport and Environment Database System (TRENDS): Maritime air pollutant emission modeling. Atmos Environ 38:2357. doi:10.1016/j.atmosenv.2004.07.038

IHS Fairplay (2011). Lombard House, 3 Princess Way, Redhill, Surrey, RH1 1UP, UK.

IMO, International Maritime Organization (2008). The International Convention for the Prevention of Marine Pollution from Ships, 1973 as modified by the Protocol of 1978 relating thereto (MARPOL 73/78), Annex VI: Prevention of Air Pollution from Ships, 2008 Amendments

IMO, International Maritime Organization (2009). The second IMO Greenhouse Gas study, UK

Jalkanen J-P, Brink A, Kalli J, Pettersson H, Kukkonen J, Stipa T (2009) A modelling system for the exhaust emissions of marine traffic and its application in the Baltic Sea area. Atmos Chem Phys 9:9209-9223. doi:10.5194/acp-9-9209-2009 
Jalkanen J-P, Johansson L, Kukkonen J, Brink A, Kalli J, Stipa T (2012a) Extension of an assessment model of ship traffic exhaust emissions for particulate matter and carbon monoxide. Atmos Chem Phys 12:2641-2659

Jalkanen J-P, Kalli J, Stipa T (2012b) Confronting future reality-the price of sulphur reductions in Baltic sea and North Sea shipping. Baltic Transport Journal 2(2012):14-17

Kesgin U, Vardar N (2001) A study on exhaust gas emissions from ships in Turkish Straits. Atmos Environ $35: 1863-1870$

Petzold A, Weingartner E, Hasselbach J, Lauer P, Kurok C, Fleischer F (2010) Physical properties, chemical composition, and cloud forming potential of particulate emissions from marine diesel engines at various load conditions. Environ Sci Technol 44:3800-3805

Stipa T, Jalkanen J-P, Hongisto M, Kalli J, Brink A (2007). Emissions of NOx from Baltic shipping and first estimates of their effects on air quality and eutrophication of the Baltic Sea. ISBN: 978-951-533028-4, available at: http://www.helcom.fi/stc/files/shipping/NOx\%20emissions.pdf. Accessed 14 Mar 2012

Wang C, Corbett JJ, Firestone J (2007) Modeling energy use and emissions from North American shipping: application of the ship traffic, energy, and environment model. Environ Sci Technol 41:3226. doi:10.1021/ es060752e 